AIDS

\section{US and French institutes in patents struggle}

TENSION is rising on both sides of the Atlantic over the matter of patents and royalties on diagnostic kits for acquired immune deficiency syndrome (AIDS). The dispute centres on the Institut Pasteur in Paris and the National Cancer Institute in Bethesda, with the Pasteur as the agcrieved party.

I. uc Montagnier, the French codiscoverer of the virus that causes AIDS, believes that the royalties earned on patents for AIDS diagnostic kits should be divided equally between the Pasteur and the United States Department of Health, whose National Cancer Institute researcher Robert Gallo also isolated AIDS virus (see page 395). "That would correspond to the two scientific contributions", Montagnier said last week.

Matters will come to a head this month when the Food and Drugs Administration is expected to approve the Pasteur test, to be marketed in the United States by the Seattle-based Genetic Systems Inc. The problem is that whereas Gallo has a US patent on the AIDS test kits the Institut Pasteur does not - even though the Pasteur filed its patent application months before the US Department of Health. In the present state of the patenting argument, the Pasteur will be obliged to pay royalties to the Department of Health on the basis of the Gallo patent, but "that would be ridiculous", Montagnier claims. Robert Nowinski, chairman of Genetic Systems, is clear on the point: "Genetic Systems does not anticipate paying royalties to the US government."

Hence there have been increasingly urgent attempts by the director of the Institut Pasteur, Raymond Dedonder, to resolve the patent issue, in particular by a possible attachment of the Pasteur's name to the existing Gallo patent. A letter from US Secretary of State for Health Margaret Heckler to Dedonder demanding further evidence of the French claim before anything could be settled led to an explosion in Paris last month - with Dedonder threatening publically to go to law against the US government "to claim our rights". These would be a share - Montagnier has said half, others have suggested more of the $\$ 100-150$ million in royalties that are expected to arise from the use of AIDS tests. For the Pasteur, which is a private institution, this would be no mean sum, equivalent to many times its annual budget.

As for the claim itself, Montagnier points out that HTLV-III (human Tlymphotropic virus III, Gallo's) and LAV (lymphadenopathy-associated virus, Montagnier's) are "extremely similar by any criteria". The viral sequences differ by only 1.5 per cent and an independent US group will publish evidence that there is no difference between the calculated restriction maps of HTLV-III and LAV, whereas there are differences among all the maps of nine other AIDS virus isolates. Montagnier sent Gallo his viral isolate in July 1983, he has claimed (Nature 310, 466; 1984), and again later in September that year. Montagnier filed his US patent application for AIDS antibody tests based on enzyme-linked immunosorbent assay (ELISA), using purified viral extracts, in December 1983, but Gallo filed his similar application only in April 1984. Gallo's application was granted in May 1985; but Montagnier is still waiting.

The Pasteur patent application emphasizes a core protein (p25) of the virus, rather than an envelope protein, to stress differences between HTLV-III and the HTLV-I and -II viruses, says Montagnier, "but the virus extract should include all viral proteins". Gallo's patent, in contrast, emphasizes the p41 envelope protein. If the two tests indeed sought different antibodies, one possible outcome would be two separate patents, but it now seems they are too similar for that to be feasible. The US Patent Office will probably be obliged to declare an "interference period" - which may last a year or more - during which time neither side would be permitted to take legal action against the other and no royalties would be paid by either party.

Although the existing tests licensed on the US market have the advantage of priority, Genetic Systems boasts that in a recent clinical trial in Australia the Pasteur test achieved 100 per cent sensitivity and specifity on 6,000 samples from 1,000 patients, a clear improvement on any of the existing tests. The difference is ascribed to the production of the virus in a cell line that does not produce contaminating HLA antigens that can lead to false positives.

Does Montagnier feel surprised at the delay in granting the patent? "What is more surprising is the speed with which Gallo's patent was issued", he says. Nevertheless, Montagnier emphasized, "I'm very confident in the American administration doing their duty without political interference - and that our patent will be accepted very soon." The natural justice of the matter was that "we've made a good contribution to this problem, and Gallo has made a good contribution, and so we should share the rights and the royalties."

Robert Walgate \& Tim Beardsley
Biotechnology

\section{New plans for regulation}

Washington

Tre White House's working group on biotechnology policy has changed its tune over how the federal government ought to plan regulation in the area. Earlier plans for a Biotechnology Science Board made up of scientific advisers from each of the five relevant government agencies have been shelved, and current thinking favours instead a committee of federal officials at assistant secretary or undersecretary level.

At the end of last year, in a plan that was far from universally popular, the Cabinet Council Working Group on Biotechnology suggested establishing a scientific advisory group analogous to the Recombinant DNA Advisory Committee (RAC) of the National Institutes of Health (NIH) within each of four agencies - the Food and Drug Administration, the Department of Agriculture, the National Science Foundation (NSF) and the Environmental Protection Agency. Representatives from each of these four committees and from RAC itself would comprise the Biotechnology Science Board. Critics of the plan feared that the new board would merely duplicate on a more elevated plane, and eventually supplant, RAC and its equivalents in other agencies, and many researchers felt that RAC's accumulated expertise sould be protected.

The committee now proposed would operate under the Federal Co-ordinating Council on Science, Engineering and Technology, which is chaired by George Keyworth, the President's science adviser. It would restrict itself to defining what the scientific issues should be for each agency and would not make decisions about individual proposals.

As currently envisaged, the new committee would include two representatives from each agency. Ad hoc subcommittees of outside advisers could be established as necessary to handle specialized questions. The committee would be chaired alternately by NIH and NSF, and the whole realm of biotechnology would be within its purview.

The new plans were outlined at a recent RAC meeting by Bernadine Healy, until last week chairman of the Cabinet Council Working Group on Biotechnology. They will be formally published next month. One issue that has already given rise to concern is how accessible, or at least visible, to the public the new committee will be. According to those working on the plan there will be public access to the individual RAC-equivalents, and some provision will also be made for access to the full committee, but the exact details have yet to be settled.

Tim Beardsley 